
Balkan Araştırma Enstitüsü Dergisi / Journal of Balkan Research Institute
Cilt/Volume 10, Sayı/Number 1, Temmuz/July 2021, ss. 77-103.

Geliş - Received: 29.10.2019

Kabul - Accepted: 20.01.2021

DOI:

ARAȘTIRMA MAKALESI - RESEARCH ARTICLE

\title{
THE RELATIONS BETWEEN KOSOVO NATIONAL PROTECTION COMMITTEE AND THE ALBANIAN GOVERNMENT DURING (1918-1924)
}

\begin{abstract}
The Kosovo National Protection Committee (KNPC), which was founded in Shkodra on May 1, 1918, was one of the most important organizations of Albanian political pluralism in the years 1918-1924. The Committee had a broad political, democratic and national program that would have played the role of the government for Kosovo and strongly represented its voice. With such a status, the Committee could play an important role in Albanian political life at that time. Hoping that the Paris Peace Conference of 1919 would resolve the Albanian question, the leadership of the Committee sent successive memoranda and telegrams respecting the independence of Albania and reversing the injustices inflicted by the Great Powers on the Albanian people in 1913. During these years, the Committee established close relations with the Albanian governments. At first, it objected to the pro-Italian capitulation policy of the Durres government and condemned its actions. Later, when the patriots decided to convene a new national congress due to the international political circumstances and the danger of the disintegration of the country, they endorsed this initiative and praised it as a historic congress. They joined the decisions of the Lusnya Congress and participated as members of the resulting national government. If one recognizes the names of the members of this organization, one can say that the KNPC was one of the most important influences in the history of Albanian statehood in the years 1918-1924.
\end{abstract}

Ilirjana KACELI*

Keywords: National Protection Committee of Kosovo, Durres Government, Congress of Lushnja

\footnotetext{
* Dr., Departament History-Geography, Faculty of Human Sciences, University of Elbasan “Aleksander Xhuvani”, Elbasan, Albania, ORCID: orcid.org/0000-0002-8228-9789, E-email: ilirakaceli@gmail.com
} 


\title{
ILIRJANA KACELI
}

\section{KOSOVA MILLLî KORUMA KOMITESİ VE ARNAVUTLUK DEVLETİ ARASINDAKI İLIŞKILLER (1918-1924)}

\author{
ÖZ
}

1 Mayıs 1918'de İșkodra'da kurulan Kosova Millî Koruma Komitesi (K M $\mathrm{K} \mathrm{K}$ ), Arnavutluk siyasi çoğulculuğunun en başta gelen teşkilatlarından biriydi. Komitenin Kosova için bir devlet rolü oynayabilecek ve onun sesini güçlü bir şekilde temsil edebilecek geniş bir siyasi, demokratik ve milli programı vardı. Bu hali ile komite, o dönem Arnavutluk'unun siyasi hayatında önemli bir rol oynayabilirdi. Paris Barış Konferansı'nın (1919) Arnavutluk sorununu çözmesi umularak, Komite'nin liderliği peşpeşe gönderdiği bildiriler ve telgraflarla Arnavutluk'un bağımsızlığına saygı duyulmasını ve Arnavutluk'un 1913'te gerilemesine sebep olan Büyük Güçlerin yol açtığı adaletsizliklerin giderilmesini talep etti. Bu yıllarda Komite Arnavutluk devleti ile güçlü ilişkiler kurdu. İlk başta, Draç Hükümeti'nin eski-İtalyan kapitülasyon siyasetine karşı geldi ve faaliyetlerini kınadı. Daha sonra vatanseverler, uluslararası siyasi şartları ve ülkenin bölünme tehlikesi ile ilgili olarak yeni bir milli kongre çağrısı yapmaya karar verdikleri zaman, bu girişimi tarihi bir kongre olarak desteklediler ve övdüler. Onlar Lushnja Kongresin'in kararlarını kabul ettiler ve ondan doğan milli devletin üyesi olarak ortak oldular. Bu teşkilatın üyelerinin isimleri dikkate alınarak, KMKK'nın 1918-1924 dönemindeki Arnavutluk'un devlet haline gelmesi tarihinin en önemli faktörlerinden birisi olduğu söylenebilir.

Anahtar Kelimeler: Kosova Millî Koruma Komitesi (KMKK), Draç Hükümeti, Luşnya Kongresi

\section{Introduction}

The First World War had brought distress to political balance amongst many countries as well as in the Balkans. The whole region was divided into two war camps. During this war, Albania was divided into four different occupation areas: the Austro-Hungarian, Italian, French and Bulgarian occupation areas. The powers of two opposing groups: the Entente (England, France and Russia) and the Central Bloc (Austria-Hungary and Germany) treated Albania as "an exchange currency". ${ }^{1}$ Following their strategic plans, both blocs deployed significant military forces in Albania. In April, 1916, Kosovo was also divided into two occupation zones: the Austrian occupation area and the Bulgarian occupation area. ${ }^{2}$

\footnotetext{
${ }^{1}$ Valentina Duka, Histori e Shqipërisë 1912-2000, SHBLU, Tiranë 2007, p. 90.

${ }^{2}$ Fitim Rifati, Kosova gjatë Luftës së Parë Botërore, Insituti i Historisë Kosovë, Prishtinë 2019, p. 156.
} 


\section{THE RELATIONS BETWEEN KOSOVO NATIONAL PROTECTION COMMITTEE AND THE ALBANIAN GOVERNMENT DURING (1918-1924)}

In this context, where the decisions of the Great Powers (1913) and of the Secret Treaty of London (1915) had denied Albanians a political Albania extending along ethnic borders, the formation of organizations with a political character and program was a necessity for the protection and liberation from the foreign occupation of Albanian lands both within the borders of Albania and abroad. Between 1913-1916, several Albanian secret organizations were founded such as: "Shkipnia", "Besa Shqiptare", "Secret Committee" of Kosovo, "Skopje Club". These organizations were the forerunners of the establishment and founding of the "Kosovo National Protection Committee" in $1918^{3}$.

During this period, Albanians of Kosovo operating inside Albania considered the international situation partly favorable for organizing a new liberation uprising in Kosovo. To this regard, at the very start of an armed uprising, an organization named the "Secret Committee" of Kosovo, based in Shkodra and headed by Kadri Prishtina, appears on the scene. It is thought that this illegal organization was established in1914, whose Kosovo members were Rexhep Mitrovica, Halim Gostivari, Salih Gjuka, Fahri Gjilani, etc. ${ }^{4}$ With the mediation of Kadri Prishtina, others joined the organization, to name some: Aqif Pashë Elbasani, Bajram Curri, Koço Kota, Salih Gjuka, Shefqet Korça and Bajram Fevziu. ${ }^{5}$

After Montenegro entered Shkodra on June 27, 1915, the activity of this organization was stopped. Even when Shkodra was under the AustroHungarian rule, the work and activity of the Committee remained silent, and its members were dispersed. The war caused several serious wounds to Albania, the country suffered great destruction and losses in people, whereas the economy was severely damaged. In these conditions, the Albanians had not only to fight to gain freedom but also to save the country from a new fragmentation. ${ }^{6}$

\footnotetext{
${ }^{3}$ Rifati, "Organizatat Pararendëse të Komitetit "Mbrojtja Kombëtare e Kosovës" (19131916)", Instituti i Historisë Prishtinë, Kosova, no.44, Prishtinë 2019, p.284.

4 Lush Culaj, Komiteti Mbrojtja Kombëtare e Kosovës 1918-1924, (Kosovo National Protection Committee 1918-1924), Instituti Albanologjik i Prishtinës, Prishtinë 1997, p. 21 24.

5 AQSH, Fondi. 446, Viti 1919, Dos. 9, dok.707-709, p. 1-2. General Program of the National Defense Committee of Kosovo

${ }^{6}$ Alban Dobruna, "The Contribution of Islamic Tariqats to the Kosovo National Protection Committee", Univers, Tiranë 2020, Number 21, p. 67.
} 


\section{ILIRJANA KACELI}

During 1918-1920, different thoughts and ideas occupied the minds of Albanian patriots whose contribution was best reflected in the creation of various organizations, associations and political parties that established the basis of political pluralism in Albania. Some Albanian patriots with progressive and democratic views ${ }^{7}$ driven by the political circumstances of the time made efforts and demanded that their lands achieve national unification, and, at the same time, tried to oppose the divisive plans of their lands. In this period, when Shkodra was placed under the international jurisdiction of the Great Powers, Hoxha Kadri, Bajram Fevziu, Sejfi Vllamasi, Sali Nivica would resume the legal work of the new Committee named "Kosovo National Protection Committee".

\section{Kosovo National Protection Committee}

The end of the Great War raised to the Albanian people the question of the existence of an independent Albanian state, its democratization, the liberation of Kosovo and other Albanian territories under the Serbo-CroatianSlovenian Kingdom. As a result, a group of Albanian patriots from Kosovo led by Hoxha Kadri Prishtina undertook the setting up of a political organization to anticipate any critical and complex situations. ${ }^{9}$

On May 1, 1918, in the city of Shkodra, they established the "Kosovo National Protection" Committee (KNP). ${ }^{10}$ Representatives of various Albanian regions inside and outside its borders took part in the launch of the works of the Constituent Assembly of the Committee. ${ }^{11}$

The main goal of this Committee was to establish an independent Albania, excluded from any kind of protectorate, to liberate Kosovo and unite it with Albania. Furthermore, the Committee aimed at extending its activity inside and outside the territories which remained under the foreign rule in order to protect the people of Kosovo, in particular, being the ones who had

\footnotetext{
${ }^{7}$ Zamir Shtylla, "Rreth krijimit e veprimtarisë së Komitetit "Mbrojtja Kombëtare e Kosovës" në vitet 1918-1920”, Akademia e Shkencave e RPSH: Instituti i Historisë, Viti XXXX (XXIII), Studime Historike, Tiranë 1986, Number 3, p. 97.

${ }^{8}$ Culaj, ibid., p. 23.

${ }^{9}$ Ekber Skëndi, Hoxhë Kadriu (Kadri Prishtina), Rilindja, Prishtinë 1992, p. 36.

${ }^{10}$ Lufta e Popullit Shqiptar për Çlirim Kombëtar 1918-1920(Përmbledhje me dokumenta), Volume I, (Eds: Muin Cami and Hidajete Luga (Bejtja), Akademia e Shkencave: Institute i Historisë \& Drejtoria e Përgjitshshme e Arkivave,Tiranë 1975, p. 76.

${ }^{11}$ History of the Albanian People, Volume III, Toena, Tiranë 2007, p. 458.
} 


\section{THE RELATIONS BETWEEN KOSOVO NATIONAL PROTECTION COMMITTEE AND THE ALBANIAN GOVERNMENT DURING (1918-1924)}

lengthily experienced the Serbian genocide. Another important claim was the return of all fragmented lands under the protection of natural Albania. To serve this aim, armed uprisings and memorandums were to be organised as well as various publications drafted by the Committee. Last but not the least, engaging in an energetic campaign against the Italian occupier seeking to impose a kind of protectorate on Albania was an important factor to unifying lands. ${ }^{12}$

The Committee also aimed to send the leadership of the organization the statistics of the population and the settlements, ${ }^{13}$ protests and memorandums addressed to representatives of the Great Powers of the time, state personalities, and progressive people in various countries. ${ }^{14}$

The activity of the Committee expanded rapidly at the end of 1918, especially in later years, and was based on the illegal activity started in May 1918. This is also confirmed by the fact that at the end of the First World War, when it began to operate legally, the Committee had a much more complete and consolidated structure than a newly formed organization could have. ${ }^{15}$ Therefore, we think that his activity had the institutional form of a legal government that would represent Kosovo in that historical period. The activity of the KNP Committee was therefore manifested in the way it was organized and operating, following an administrative regulation. The Committee took decisions, drafted the memorandums and correspondence, assigned duties and responsibilities to each member, and was managed by a central Committee operating in various branches. The Committee had a significant geographical presence and a large number of members inside and outside the country.$^{16}$

The program of this Committee consisted of three sections or core issues, where the main directions of the further activity of the organization in the strategic and tactical plan were clearly, concisely and accurately reflected. At the very first and core section of the program, the main goal of the KNP Committee was specified, and emphasized as: "to endeavour and demand in

\footnotetext{
${ }^{12}$ Dobruna, ibid., p. 68.

${ }^{13}$ AQSH, Fond. 446, Viti 1918, Dos.26, p. 4. Population statistics of Gjakova district in 1918.

${ }^{14}$ AQSH, Fond.446, Viti 1920, Dos.11, p.1. The list that various people sent to the Committee regarding the massacres of Serbo-Montenegrins against the Kosovo population. (Albanian Manuscripts).

${ }^{15}$ Lush Culaj, "Free and Self-guiding Albania”, Bujku, Prishtinë 24 April 1998, p. 13.

${ }^{16}$ Shtylla, ibid., p. 101.
} 


\section{ILIRJANA KACELI}

the presence of the great Entente Powers the unification of the provinces of Kosovo (Skopje, Kumanovo, Presevo, Tetovo, Gostivar, Kaçanik, Ferizaj, Gjilan, Prishtinë, Vuçiternë, Mitrovicë, Yeni Pazar, Rozhajë, Peja, Plavë, Guci, Gjakovë, Prizren) in a free and self-governing Albania". ${ }^{17}$ These were the territories that generally constituted the regions with Albanian population occupied by Serbia and Montenegro in 1912. This is evidenced by the fact that Elez Isufi was associated with the Kosovo Committee from the beginning and fought for the accomplishment of his main goal, that is, the unification of Kosovo and Dibra with Albania. Elez Isufi himself was friends with the chairman of the Committee, Hoxha Kadri Prishtina. ${ }^{18}$

The organization of the uprising in Kosovo, its preparation, the correspondence with its subsidiaries, the vigilance in conducting combat undisclosed operations showed that its activity during this period was overwhelming and highly dominant, as well as strongly supported by the people, especially in the Northern Highlands. ${ }^{19}$

The second point of the program envisaged as a priority task of the Committee is the protest against the anti-Albanian policy pursued by the Serbian government towards the Albanian people. The third and final point of the KNP Committee's founding program foresees the election and sending of a delegation to defend Albanians before the Great Powers. ${ }^{20}$

Being for the tasks it aimed at accomplishing in its program, the geographic scope or the composition and the number of its members, the Kosovo Committee would become one of the most important political organizations in Albania. ${ }^{21}$

The establishment of the KNPC was one of the many enterprises initiated at that time by Albanian social leaders and politicians with the aim of getting politically organized, coordinating their actions in accordance with the politically-established tasks, to name, the achievement of a national

\footnotetext{
${ }^{17}$ AQSH, Fondi. 446, Year 1918, Dos. 1, p. 1.

${ }^{18}$ Bajram Xhafa, Lufta e Dibres 1920: qëndresa dibrane ndaj pushtimit ushtarak jugosllav në vitet 1918-1921, (Dibra war 1920: Dibra resistance to the Yugoslav military occupation in the years 1918-1921), Camaj-Pipa, Shkodër 2001, p. 81-82.

${ }^{19}$ Pal Doci, Hoxha Kadri Prishtina jeta dhe vepra, (Hoca Kadri Prishtina life and works), Geer, Tiranë 2005, p. 23.

${ }^{20}$ AQSH, Fondi 446, Year.1918, Dos. 1, p. 1.

${ }^{21}$ Shtylla, ibid., p. 101.
} 


\section{THE RELATIONS BETWEEN KOSOVO NATIONAL PROTECTION COMMITTEE AND THE ALBANIAN GOVERNMENT DURING (1918-1924)}

movement to save the lands from the invaders. The Committee was founded in Shkodra as the most convenient place, among other reasons, due to the fact that this town was closer to Kosovo where the oppressive regime of Belgrade was located. ${ }^{22}$ Second, many Albanians who left Kosovo due to the massacres and opressions from the Serbs were refuged inside the city. Third, representatives chose Shkodra, since the city was attributed a special status being under international rule. ${ }^{23}$

The internal political factors in presenting, judging and protecting the national existence as well as their efforts using international diplomacy would provide the Committee massive support from all Albanians and the most democratic clans of that time. The Committee's activity in the establishment and strengthening of the Albanian national movement shall be seen as a cooperation between different social strata in Kosovo and Albania like the intellectuals, merchants, workers, craftsmen, students, etc.

Though it was named "Kosovo National Protection Committee", ${ }^{24}$ it was established on regional interests and supported the general platform of the Albanian National Movement. The Leaders representing Kosovo were: Kadri Prishtina, Bedri Pejani, Bajram Fevziu, Riza Dani, Hysni Curri, Hasan Prishtina, Qerim Begolli, Beqir Vokshi, Qazim Bakalli, Tafil Boletini etc., ${ }^{25}$ warriors and popular leaders as Azem Bejtja, Sadik Rama, Ramadan Shabani, Zef Gjidoda etj. Other outstanding activists were Rexhep Mitrovica and Sali Hoxha from the branch of Durrës, from Labëria: Sali Nivica, Sali Gjuka, from Kolonja Sejfi Vllamasi; from Shkodra Hamit Gjylbegu. Later, other patriots from Elbasan became part of the initiative such as Aqif Pashë Elbasani, Ahmet Gashi, Qamil Bala and other personalities and patriots from the Dibra region and all over Kosovo joined them. From the branch of Plava, Gucia and

\footnotetext{
${ }^{22}$ Muin Çami, On the establishment of the Committee "Kosovo National Protection", and its political orientation, in: (Summary with paper releases "Kosovo National Protection Committee", Akademia e Shkencave të Shqipërisë; Instituti i Historisë-Tiranë, Instituti i Historisë-Prishtinë, Tiranë 2004, p. 45.

23 General G. F. Phillips and the Kosovo National Protection Committee (Historical documents from the British Archives 1913-1921), (Ed. Ethem Çeku \& Bejtullah Destani), Albanian Institute of National Affairs-Tirana, The Centre for Albanian Studies-London, Tiranë 2015, p. 53.

${ }^{24}$ Culaj, ibid., p. 28.

${ }^{25}$ Sejfi Vllamasi, Ballafaqime Politike në Shqipëri (1897-1942), Marin Barleti, Tiranë 1995, p. 111.
} 


\section{ILIRJANA KACELI}

Rugova distinguishing members were Jusuf Hoti, Shaqir Muslia, Çun Mula, Adem Smajli, Hasan Ferri etc. ${ }^{26}$

According to its Statute, the Committee had two headquarters, one in Shkodra and the second one in Geneva, Switzerland. The two headquarters were administered by the Central Council, which consisted of seven members. Kadri Lutfulla Prishtina, known as Hoxha Kadri Prishtina, was elected chairman. He was born in the city of Pristine and was later educated in several high schools in Istanbul. In 1904, he received the title of Professor in Religious Law Sciences. ${ }^{27}$ Major Hysni Curri was appointed to organize the armed forces, Bedri Pejani was in charge of foreign relations, while Sali Nivica ran the newspaper "Populli".

The activity of the Committee would extend geographically both inside and outside Albania. They maintained strong close relationships with Albanians in exile as with the Istanbul colony, the Albanians of Plava and Gucia, Skopje, Novi Pazar and other areas in the region. In addition to the branches established in Kosovo, especially the powerful branch of Gjakova, ${ }^{28}$ the Committee had extended its activity and network in Prizren, Pristine, Ferizaj, Gjilan, Skopje, Pej Podrime (Anadrini), Rahovec, Vushtrri and in many towns and villages of Kosovo and other areas. ${ }^{29}$

Unlike other branches in Albania, where the development of the National activity of the Committee was easier, the branches and activities of the Serbo-Croatian-Slovenian occupied Kosovo were illegally organized. ${ }^{30}$

It was such circumstances in Kosovo that dictated this powerful national organization or the government of Kosovo in exile be the brain of the Kosovo Liberation Movement, where its main activity would be developed in the dearest homeland, Albania.

\footnotetext{
${ }^{26}$ Tahir Zaimi, The waters of life and the tears of the heart, Bruksel 1970, p. 86-88.

${ }^{27}$ Eqerem Bej Vlora, Memories 1885-1925, (Transl: Afrim Koçi), Shtepia e Librit dhe Komunikimit, Tiranë 2003, p. 90.

28 Alban Dobruna, "Gjakova and Kosovo National Protection Committee (1918-1924)", Historical Science Series, Gjurmime Albanologjike, Number 48, Prishtinë 2018, p. 185.

${ }^{29}$ Kristaq Prifti - Zamir Shtylla, "Kosovo National Protection Committee and its activity for liberation and national unity", Studime Historike, Number 4, Tiranë 1988, p. 139.

${ }^{30}$ Culaj, op.cit., p. 35.
} 


\section{THE RELATIONS BETWEEN KOSOVO NATIONAL PROTECTION COMMITTEE AND THE ALBANIAN GOVERNMENT DURING (1918-1924)}

\section{The political activity of the KNP Committee and the Government of Durrës}

Since early May 1918, the Committee leaders and its founders would operate pursuant to the program they formulated taking special care of the Albanian issue as a whole, granted that the fate of Kosovo was linked to the fate of Albania's motherland. The entire ongoing effort of this political group was to develop a highly significant political visionary program through which the KNP Committee members exercised great influence on the political life of Albanians during 1918-1924. ${ }^{31}$

The Serbo-Italian rivalry and their territorial claims towards Albania were the main burden on Albania. Italy had the support of the Great Powers which, on October 7, 1918, decided to implement the decisions of the Secret Treaty of London (1915) by recognizing Italy the right to occupy Albania. Therefore, the patriotic activity of the Kosovo National Protection Committee was mainly focused in two directions: first, in the political commitment for the liberation of Albanian lands as natural territories of the Albanian state; secondly, and parallel to these efforts, in case of failure, the Committee was to organise the National Liberation Movement. ${ }^{32}$

On several occasions, the Kosovo Committee addressed the Prime Ministers and Foreign Ministers of the Great Powers, as well as other highranking world personalities, with letters and protest notes on the situation in Albania, especially in Kosovo. The aim was to raise awareness of the Albanian issue in the international arena. ${ }^{33}$ In addition to its primary duties, the Committee dedicated great importance into stabilizing the situation within the Albanian state.

As the war was coming to an end and the Great Powers were preparing to officially open the proceedings of the Paris Conference, Albania had not yet set up a government to represent itself and a program that would address and take care of the internal problems of the country at the Conference. In such circumstances, Albania went through a diplomatic-

\footnotetext{
${ }^{31}$ Milazim Elshani, The Albanian State and Kosovo 1912-1939, University of Tirana, Faculty History-Philology, Unpublished Doctoral Thesis, Supervisor: Prof. Dr. Vlentina Duka, Tiranë 2016, p. 9.

${ }^{32}$ Skëndi, op.cit., p. 42.

${ }^{33}$ Skëndi, op.cit., p. 58.
} 


\section{ILIRJANA KACELI}

military battle, which resulted in a truncated Albanian state as well as a political infrastructure dominated by strong contradictions. ${ }^{34}$

Being these the conditions, one of the most urgent demands to put forward by the Albanian political forces was the forming of a government. The official request for this formation was submitted in writing to the Entente Powers, which at the same time were also the invaders of the country. On November 18, a group of patriots, including the KNP Committee, addressed a letter to the French General De Furdu, commander of Allied troops in Shkodra, urging him to "form an Albanian ad interim government functioning as a single administration for all Albanian territories included in the political borders that the London Conference set for independent Albania". ${ }^{35}$

The formation of the government was carried out by the Congress of Durrës held on December 25, 1918, with the participation of several representatives from many provinces of the country, mainly from those of the Italian occupation zone. ${ }^{36} \mathrm{~A}$ delegation of the Kosovo Committee headed by Hoxha Kadri also participated in the Durrës Congress. Throughout the discussions, Durrës Congressional Delegates ${ }^{37}$ took into account the principles of nationality and self-determination, which is the reason why they dismissed some of the terms of the Secret Treaty of London (1915) that seriously affected the territorial integrity of Albania, and, then, it was them who decided to give way to an ad interimgovernment under the motivation "this was what the Albanian people wanted, and it doesn't matter if Italy was to accept it or not". ${ }^{38}$ Turhan Pashë Përmeti ${ }^{39}$ was elected head of the government of Durrës.

The Congress drafted a program to be followed by the government; at the same time a government delegation led by Turhan Pasha Përmeti was

\footnotetext{
${ }^{34}$ AQSH, Fondi. 446, Viti 1918, Dos. 29, dok. 707-934, p.1.

${ }^{35}$ Archives du Ministére des Affaires Etrangéres de France. Arcives Diplomatiques (shortAMAE), Serie: Europe 1918-1929, Albanie, vol.10, (Paris) p.153-154; AQSh, Fondi. 446, Viti 1919, Dos. 27, p.1. A letter from the KNP Committee addressed to the garrison commander is to Shkodra, to the French general B. De Furtu, on November 17, 1918.

${ }^{36}$ Marenglen Verli, Kosovo Albanian challenge in the history of a century, Botim Inpex, Tiranë 2007, p. 85-98.

37 The Congress of Durrës was convened on December 25, 1918. Paskal Milo, Albania's Foreign Policy, Volume I (1912-1939), Toena, Tiranë 2013, p. 370.

${ }^{38}$ Lef Nosi, Dokumente Historike 1912-1918, Institutit i Historisë, Tirana 207, p. 293.

${ }^{39}$ Lavdosh Ahmetaj, Albania Paris Peace Conference and Albanian delegations 1918-1921, Vestprint, Tiranë 2012, p. 83.
} 


\section{THE RELATIONS BETWEEN KOSOVO NATIONAL PROTECTION COMMITTEE AND THE ALBANIAN GOVERNMENT DURING (1918-1924)}

elected to represent Albania in the Peace Conference in order to defend the Albanian cause.

The Congress of Durrës could not carry out the works in the spirit required by the Italians because of the attitude and efforts of the delegation of the KNP Committee. Hoxha Kadri would send Hysni Curri to Durrës to help establish the Albanian administration in the areas occupied by the Serbs, due to the lack of Albanian government in those areas. After getting familiar with the activity of the government of Durrës, their attitude, the inability to solve the problems of the people, the KNP Committee soon opposed the pro-Italian capitulative policy followed by several members of the government, considering that such policy opposed the national aspirations of the Albanian people. The Kosovo Committee, precisely its secretary, Bedri Pejani, condemned the government of Durrës for laying the path of cooperation with Italy regardless of the Committee's efforts to establish a protectorate over Albania. ${ }^{40}$

During the meeting with the representatives of Plava and Gucia, the chairman of the Kosovo Committee, Kadri Priştina himself would openly oppose Turhan Pasha's idea of replacing Albania's independence request with Albani"s autonomy and openly questioned the reason of such "ruthless Italian protectorate, as if Albania could not exist otherwise". He emphasized, "The Committee will not plead with the Italians and will not undertake any commitment to them." He would then write "there is not a nation in the world that once it gains its freedom it shall beseech entering into the protectorate of a foreign state." ${ }^{\prime 1}$

The members of this government, Hoxha Kadri and other delegates, were asked to represent all Albanians at the Peace Conference in Paris.

Nevertheless, it must be emphasized that the Albanians at the Peace Conference did not appear united but represented by several delegations. The government of Durres, which was following the dictate of Italian politics, openly vetoed the presence of the Kosovo delegation composed of Hasan

\footnotetext{
${ }^{40}$ Hakif Bajrami, Bedri Pejani: a life and a death for ethnic Albania 1885-1946, Fjala, Prishtinë 1994, p. 16

${ }^{41}$ Culaj, Komiteti Mbrojtja Kombëtare e Kosovës 1918-1924, p. 44-45.
} 


\section{ILIRJANA KACELI}

Prishtina, Bajram Curri and Salih Gjuka in this important international forum. $^{42}$

Unable to have a representative at the Conference, the Committee KNP trusted the duty of representation to two prominent Albanian personalities, Gjergj Fishta and Mithat Frashëri, asking them to present to the Great Powers the request for Albania to join with all the cities and provinces occupied by Serbia-Montenegro in 1912-1913, where the majority of the population was Albanian.

The Committee accompanied each request with statistics and detailed information on the composition of the Albanian population along with a map prepared by Ali Shefqeti through which they would prove to the Great Powers the righteousness to finally solve the Albanian cause by allowing all Albanian lands to be united in one single country.

The Italians' practices, the policies they pursued in Albania by bringing religious disputes between individuals of different political groups or pushing people not to pay taxes and lower the prestige of the government of Durrës, had the leaders of the Committee think that other secretive imperialist intentions (of occupation) were behind such actions and disagreed with their politics in Albania.

In the proclamation of January 1919, where they publicly expressed their attitude towards the Italian and French politics in Albania, they declared that "its main goal is to establish an independent Albania excluded from any kind of protectorate, to liberate Kosovo and unite it with Albania, and that it wll refute anyone who will oppose this goal". ${ }^{43}$

In Shkodra the chairmanship of the Committee did not underestimate the danger of Italy in comparison with that of the two neighboring Balkan monarchies, the Serbo-Croatian-Slovenian Kingdom and Greece.

The KNP Committee did not agree either with the political position of the Prime Minister of Durrës (Turhan Pasha), the government delegation

42 Hasan Prishtina (Summary of Documents 1908-1934, (ED.) Kujtim Nuro \& Nezir Bata, 8 Nëntori, Tiranë 1983, p. 108.

${ }^{43}$ Lufta e Popullit Shqiptar për Çlirim Kombëtar 1918-1920(Përmbledhje me dokumenta) Volume I, (Eds.Muin Cami \& Hidajete Luga (Bejtja), Akademia e Shkencave: Institute i Historisë \& Drejtoria e Përgjitshshme e Arkivave, Tiranë 1975, Doc. 43, p. 75. 


\section{THE RELATIONS BETWEEN KOSOVO NATIONAL PROTECTION COMMITTEE AND THE ALBANIAN GOVERNMENT DURING (1918-1924)}

in Rome and Paris, or with the pro-Italian orientation of some members of the government, and their submission that the activity of the Albanian national movement be limited to only two neighboring monarchies respectively. ${ }^{44}$

Moreover, they did not agree with the presentation of Italy as the "protector" of Albania, since Italy was not ready to give up its claims regarding the protectorate and the annexation of Vlora.$^{45}$ In such conditions, on March 16, 1919, a memorandum was addressed to the four Ministers of Foreign Affairs of the four Great Powers directly, stating that the Albanian state should have the political status of "a simple and complete independent state". ${ }^{46}$

The tensions escalated even more when the newspaper "Populli" wrote: "When will Italy show us with facts that it gives up on Vlora and the colonization of Albania?". The commander of the Italian unit would react immediately against the articles of this newspaper, which would later ask the French general Baurdi de Furtu, the leader of the allied troops in Shkodra, to take measures against this newspaper because it published systematic articles against Italian politics. ${ }^{47}$

The Committee's protests and requests continued despite the news that the Paris Conference was approving the claims of Italy, Greece and Yugoslavia and that Korça was to be given to the Greeks. Pursuant to the Titoni-Venizelos agreement of July 29, 1919, the chairmanship of the Committee gave instructions that, besides the diplomatic means, armed resistance against foreign invaders was to be used to protect the territories.

This agreement was received with deep indignation throughout the country. Italian policy in Albania was completely compromised, while for the Albanian patriots the shock reached its peak. In this situation, in August a call

\footnotetext{
${ }^{44}$ Muin Çami \& Marenglen Verli, Albania at the Peace Conference (1919-1920), Akademia e Shkencave të Shqipërisë, Kristalina-KH, Tiranë 2015, p.186.

45 "There is independence in autonomy", and "On issues of the day", Populli, Shkodër, 19, 23 March 1919.

${ }^{46}$ Memorandum published in Albanian and French in the newspaper, Populli, Shkodër, 19 March 1919.

${ }^{47}$ Arcives du Ministére de la Guerre de France. Archives historiques de l'Armee de Terre (Guerre 1914-1918), (AMG), (Paris), Kart.20, nr.272, d.4. Letter from Major Molinero, commander of the Italian garrnison in Shkodra, dated April 1, 1919, to the French general Bardi de Furtu.
} 


\section{ILIRJANA KACELI}

was sent to the KNP Committee to resist any foreign power that acted against the interests of the Albanian people. ${ }^{48}$

On August 31, 1919, the KNP Committee refered the devolution of Korça as a destructive news for Albania. "The shadow of death was about to cover the homes, villages, cities and mountains, because homeland was in danger". ${ }^{4}$

Despite the efforts to prepare the uprising program for Kosovo, there was an increasing number of members in this Committee. It is ipoortant to emphasize that the revenues were quite scarce because the activities of the Committee were assisted and supported only by the economic assistance of Albanians inside the country, therefore, at the time of the uprising in Kosovo, the Committee began to seek help from Albanian brothers living and working abroad. As evidenced in a letter, sent in August 1919, from Kadriu to Mr. Mihal Grameno, the representative of the Albanian Political Party in America at the Paris Peace Conference, Hoxha Kadri highlights the intrigues that Italy and Yugoslavia were playing at the expense of the country, its position and with disregard to any sacrifice of the Albanian brothers in Kosovo and Albania. During the time, the Committee was endeavouring to protect Albanian rights in Kosovo, and supported Albania seeking mediation to the Albanian brothers living in America to help them economically. ${ }^{50}$

\section{The Committee relations with the Albanian Government 1920-}

\section{4}

At the end of 1919, Hasan Prishtina as a representative of the Committee managed to go to Paris to defend the Albanian cause. The Kosovo Committee joined the efforts of all the patriotic and democratic forces of Albania to further strengthen the independent Albanian state and its democratization.

Specifically, the leaders of the Committee, Hoxha Kadri Prishtina and Hasan Prishtina, supported the initiative of the country's patriotic forces to convene in Lushnja, in January 1920, a general national Congress which

\footnotetext{
${ }^{48}$ AQSH, Fondi 446, Vitit 1919, Dos.12, 31 August 1919.

${ }^{49}$ Lufta e Popullit Shqiptar për Çlirim Kombëtar 1918-1920 (Përmbledhje me dokumenta) p. 347.

${ }^{50}$ Rudina Mita (Todri) \& Hysen Kordha, Albanian political pluralism during the period 19141924, Ramagraf, Elbasan 2011, p. 229-230.
} 


\section{THE RELATIONS BETWEEN KOSOVO NATIONAL PROTECTION COMMITTEE AND THE ALBANIAN GOVERNMENT DURING (1918-1924)}

would unite the Albanians and oppose the plans of the Paris Peace Conference to fracture Albania pursuant to the provisions of the London Treaty of 1915.

The Kosovo Committee exerted considerable pressure on the Durres government. It not only formally sought explanations for the activity, but also forced the government to hold positions on important issues. One example was that of December 14, 1919, when the Italian government announced the appointment of a high commissioner to the Albanian government of Durres. The chairman of the Kosovo Committee asked the government for an explanation of the action taken, "upon what international decision had this commissar been sent from Italy, and what position had our government and our delegation in Paris taken prior to such an intervention?". ${ }^{51}$

While trying to convene the Lushnja National Congress, the Committee was vigilant to eliminate any intrigue or sabotage coming from inside or outside. Regarding these actions, the Kosovo Committee assigned Rexhep Mitrovica as a representative to help in the preparations of this Congress. He urged Hoxha Kadri to congratulate the municipality of Lushnja on the initiative taken to hold this nationwide rally. He further explained in his letter the way the local organisers of the Lushnja Congress were under observation by Italian agents. ${ }^{52}$ The government of Durres and the Italian occupiers made not only numerous efforts to thwart the convocation of the Congress but also organized attacks against the Congress organizers.

On January 21, 1920, under the chairmanship of Aqif Pasha Elbasani, the Lushnja congress was opened, which held its holidays until January 31, 1920. It was attended by 50 delegates from all provinces inhabited by Albanians.

Throughout January 1920, the newspaper "Populli", serving as the spokesperson of the Kosovo Committee, dedicated part of its content to the Congress of Lushnja condemning and denying the government of Durres. The newspaper played a significant role in the organization of the Lushnja Congress supporting and promoting the new National Government emerging from the Congress. Through several published articles, the newspaper urged the readers to fight for the implementation of the decisions of this Congress.

\footnotetext{
${ }^{51}$ Doçi, ibid., p. 36.

${ }^{52}$ Aqif Pashë Elbasani (1860-1926), (Summary of documents), (Eds: Mentar Belegu, Hysen Kordha, Rudina Mita), Bashkia Elbasan, Tiranë 2012, p. 194-195.
} 


\section{ILIRJANA KACELI}

They invited Albanian patriots to attend this Convention and regarded it as a historic convention that would provide salvation to the homeland and bring about a truly patriotic government. ${ }^{53}$

The Committee also appointed its delegation to the Lushnja Congress, namely, Hysni Curri, Xhemal Prishtina and Rexhep Mitrovica. ${ }^{54}$ The committee had further instructed its delegates on the political position they should take. The delegates were mandated to express in front of the Congress the Kosovo Committee's distrust against the Government of Durres. According to the delegates, the had been acting inadequately and had not taken any measures to liberate Kosovo, instead, they had shown indifference for this part of Albania.

This government had the same indifferent attitude towards the provinces of Luma, Has, and Lower Dibra, which the London Conference (1913) recognized as part of political Albania. The Government of Durres had not taken any action to help the occupied provinces cope with the violence and liberate them from the Serbian army. Consequently, the Government of Durres had not taken any action even when 13,000 Serbian soldiers attacked Plava, Gucia and Rugova, etc., and left thousands of women and children be massacred. This government showed no care about the fate of its people. ${ }^{55}$

Therefore, based on the mistakes of the Government of Durres, the Chairmanship of the Committee considered the following issues as mandatory to be addressed at the Lushnja Congress:

a. To overthrow the Government of Durres and replace it with a credible new one.

b. To change the delegation that represented the Albanians in Paris.

c. To denounce the Serbian atrocities on Kosovo and ask that the case be handed over to the governments of Antanta and the Paris Peace Conference.

\footnotetext{
53 Kristaq Prifti, Contribution of the "KNP" Committee for the restoration of Albania's independence and for national unification (1918-1924), in: (Summary with paper releases "Kosovo National Protection Committee", Akademia e Shkencave të Shqipërisë; Instituti i Historisë-Tiranë, Instituti i Historisë-Prishtinë, Tiranë 2004, p. 24.

${ }^{54}$ Later Recep Mitrovica sends a letter to Hoca Kadriu asking him to substitute him at the Congress and informs him about the situation created. Moreover, he asks Hoca Kadriu to write to Ahmet Zogu wether he would go to the Congress, too. (back-translated from Albanian).

${ }^{55}$ AQSH, Fondi. 446, Viti 1920, Dos. 16, p. 12.
} 


\section{THE RELATIONS BETWEEN KOSOVO NATIONAL PROTECTION COMMITTEE AND THE ALBANIAN GOVERNMENT DURING (1918-1924)}

d. To renew the protest with rallies organised in every city when the congressional delegates returned to their seats.

Furthermore, the delegation of the new Lushnja Government sent in Paris was asked to submit two issues to the Great Powers: first, the safeguard of a solely independent Albania and, second, the unification of the remaining territories of Kosovo, Monastery, Cameria, and Ulcinj provinces which had been under Serbian and Greek rule since 1913. ${ }^{56}$

The Kosovo Committee was always well-informed about the work that was being done and the obstacles the initiators of the convened Congress faced. The concern about a possible foreign intervention, the patriotic momentum of the people, the unmasking of the Government of Durres, as well as the influence of military and civilian officials opposing this Government in the Northern provinces, and the dissatisfaction due to the capitulating and anti-national policy brought further abandonment of this government. The initiators were more likely to receive instructions and report back to the branches of the Kosovo Committee in these provinces rather than to representatives of the Government of Durres. In other words, the power of the Government of Durres in the Northern provinces had been simply formal, while that of the Kosovo Committee was real and intact. ${ }^{57}$

The confidence in the decisions of the Lushnja Congress, led the members of the KNPC leadership to declare that "Albanians are ready to sacrifice, even if spilling the last drop of their blood, against any action that may jeopardize the independence of Albania and its territorial integrity". ${ }^{58}$

At the Lushja Congress, the election of a new government headed by President Suleyman Delvina was an important decision. The government cabinet would include: Eshref Frashëri, vice president; Mehmet Konica, Minister of Foreign Affairs; Ahmet Zog, Minister of Internal Affairs; Sotir Peci, Minister of Education, Hoxha Kadri, Minister of Justice; Ndoc Çoba Minister of Finance; Ali Riza Kolonja Minister of War. ${ }^{59}$ The new government was established in Tirana on February 11, 1920, year when Tirana become the capital of Albania. Left without an administration and

${ }^{56}$ AQSH, Fondi. 446, Vitit 1920, Dos. 16. p. 13.

57 Doçi, ibid., p. 39.

58 Culaj, op.cit., p.106.

${ }^{59}$ AQSH, Fondi 152, Viti 1920, Dos. No. 9, p.1-7. Record of the Meeting of the Congress of Lushnja, 21 and 28-31 January 1920. 


\section{ILIRJANA KACELI}

abandoned by the people, the Government of Durres was forced to leave and hand over the government archives. Soon the Government of Tirana expanded its authority everywhere and found the support of Albanians at home and abroad. This government began its work independently and did not accept any Italian or other foreign control on its activities.

Once the Chairman of the Kosovo Committee, Hoxha Kadri Prishtina became a member of the cabinet of Sulejman Delvina's government, ${ }^{60}$ as the Minister of Justice, he managed to unite administratively the city of Shkodra with the Albanian National Government emerging from the Lushnja Congress. ${ }^{61}$ This action was an important milestone for the national movement and the new government. At the National Council (Parliament) Hoxha Kadri presented a detailed plan called "action program to be implemented in case of the unification of Shkodra with the Government of Lushnja". ${ }^{62}$ The main points of this plan were the political, military and administrative aspects of the issue. This plan also defined the attitude towards the Serbian government, which at that time still held a wide range of Albanian lands from Dibra to Tarabosh and Buna. ${ }^{63}$ On March 11, 1920, Hoxha Kadri announced to the whole country that the city of Shkodra joined politically and administratively the National Government of Albania. ${ }^{64}$

On 27 March 1920, the National Council (Parliament) was convened in Tirana. At the core of the Council and the Government, there were three important quests: first, securing an independent Albanian state, its international recognition and the territorial integrity; second, extending and strengthening the state authority in all the provinces of the country by establishing advanced legal grounds; third, helping the country step away from social backwardness and ensure national development and emancipation.

The National Council instructed Tirana Government to take all the appropriate measures to strengthen its power and unite the occupied provinces. The Government task was to hold talks with Italian troops. The MCR Committee and its chairman understood that Italy continued to pose a threat to Albanians. On 25 May 1920, in the capacity of Minister of Justice,

${ }^{60}$ History of the Albanian People, Volume III, Toena, Tiranë 2007, p. 139-150.

${ }^{61}$ Culaj, ibid., p. 150.

${ }^{62}$ AQSH, Fondi. 446, Viti 1920, Dos. 9, p. 1-7.

${ }^{63}$ AQSH, Fondi. 446, Viti 1920, Dos. 9, p. 1-7.

${ }^{64}$ AQSH, Fondi. 446, Viti 1920, Dos. 29, p. 5. 


\section{THE RELATIONS BETWEEN KOSOVO NATIONAL PROTECTION COMMITTEE AND THE ALBANIAN GOVERNMENT DURING (1918-1924)}

Hoxha Kadri sent a letter to the Italian representative in Durres urging Italy to relinquish the occupation of Durres and Vlora, as this act violated the territorial integrity of Albania, and "at the same time, this action could encourage the Serbo-Croatian-Slovenian Kingdom to invade Shkodra, as well as the Greek government to invade Gjirokastra and Korça" ${ }^{65}$. During the talks held in Shkodra, in March 1920, as well as in Durres, in May of the same year, Hoxha Kadri, through his speech in front of the Parliament, clarified that he sought the trust of the Government and expressed his wish that the work be expanded even more openly. ${ }^{66}$

The activity of the Kosovo Committee was ubiquitous. In order to save Albania from the invading foreign states, the Committee's leaders defended the view that only by eliminating the Italian claims on the one hand, could the claims of Serbia and Greece be successfully withstood on the other. ${ }^{67}$

Following the developments of the Lushnja Congress on February 1, 1920, the Kosovo Committee addressed a circular to the entire Albanian nation informing the people that Albania was falling apart just as Poland once did, even though the Albanians had gained independence before the World War. ${ }^{68}$ At the same time, in the circular, it was said, "Oh brothers, we must take possession of our lands and our freedom, and so we must prove that we deserve freedom. Then, we can believe that we will earn even the amity of those Great Kingdoms that are trying to tear us apart today." 69

The Kosovo Committee held protests during which it declared that they would fight until no one was left alive to stop the decision of the Great Powers, that would result in the disappearance of the Albanian nation, and that the Committee would never allow them to separate any single inch of Vlora, Shkodra, Gjirokastra and Korça from their motherland, Albania. The Committee even proved to be decisive and played an important role in

${ }^{65}$ Lufta e Popullit Shqiptar për Çlirim Kombëtar 1918-1920, op.cit., p.3 9-40.

${ }^{66}$ Bisedimet e Këshillit Kombëtar, (National Council Talks), Year 1920/1921, Shtypshkronja Mbrothësia, Tiranë 1923, p. 64.

${ }^{67}$ AQSh, Fondi. 446, Viti 1920, Dos. 15, p.19,

${ }^{68}$ AQSH, Fondi. 446, Viti 1920, Dos..15, p.19,

${ }^{69}$ Xheladin Shala, "The role of the "KNP" Committee in the Albanian-Serbian wars during the years 1918-1921", in: (Summary with paper releases "Kosovo National Protection Committee"” Akademia e Shkencave të Shqipërisë; Instituti i Historisë-Tiranë, Instituti i Historisë-Prishtinë, Tiranë 2004, p. 120. 


\section{ILIRJANA KACELI}

organizing a resistance against the Serbian military intervention in Northern Albania, especially in the district of Shkodra, in the last days of July $1920{ }^{70}$

In the Koplik war, the Committee contributed to the mobilization of the 2,200 volunteer armed forces from Shkodra and Malesia e Madhe to defeat the Serbian-Montenegrin forces. ${ }^{71}$ Albania not only resolved the national question but had to strive to preserve the London Conference defined borders.

The Italian government acknowledged their failure in Albania and on August 2, 1920, in Tirana, they signed a protocol through which Italy respected Albanian sovereignty over Vlora and the territorial integrity of Albania. ${ }^{72}$ The years 1920-1924 in Albania are considered to be a period of pluralism of opinions and the peak of political life, and when Albanians tried to fully organize the Albanian state and carve the proper shape of its government.

However, Albania and the Albanians had to fight with their own forces to survive politically and could not depend on the help of another power. Internally, there were major obstacles between political philosophies for the implementation of a new political order, the battles and discussions in the Albanian Parliament were fierce and showed quality and depth in the opinions expressed.

Following the resignation of Suleyman Delvina's government on November 14, 1920, the battle for power would be intensified through various political groups. This aggravation of opinions also appeared in the ranks of the "KNP" Committee. For various reasons, some particular members tried to overthrow Hoxha Kadri and divert the direction of the Committee's activity. The Durrës branch led by Halim Gostivar, Sali Vuçiterna and Rexhep Mitrovica helped in such overthrowing. These representatives, after failing to achieve the goal against Hoxha Kadri, poured a stream of accusations on Hasan Prishtina. This branch activity was of minor impact, but the accusations it spread would serve Ahmet Zog in the future.

${ }^{70} \mathrm{Z}$. Shtylla, "About the establishment of the activity of the Committee "National Defense of Kosovo" in the years 1918-1920", Studime Historike, Viti XXXX (XXIII), Number 3, Tiranë 1986, p. 111.

${ }^{71}$ E. Skendi, op.cit., p. 128.

${ }^{72}$ Georges Castellan, History of Balkans, (Transl.) Arben Puto \& Luan Omari, Çabej, Tiranë 1996, p. 451. 


\section{THE RELATIONS BETWEEN KOSOVO NATIONAL PROTECTION COMMITTEE AND THE ALBANIAN GOVERNMENT DURING (1918-1924)}

However, in the first elections of April 21, 1921, Hoxha Kadri was elected MP in the Albanian Parliament as head of the KNP Committee. ${ }^{73} \mathrm{He}$ was appointed vice-chairman of the Parliament and a member of the Justice and Appeals Committee. ${ }^{74}$ In December 1921, due to the "government crisis" that occurred, the aggravation of relations with Zog, forced Hasan Prishtina and his government, including Hoxha Kadri as Minister of Justice, to resign. ${ }^{75}$

On December 14, 1921, Ahmet Zog entered Tirana, took command of the gendarmerie, besieged the city and immediately summoned the Parliament that arbitrarily abolished the mandate of the representatives of Kosovo.

Hoxha Kadri and the Kosovo Committee did not like the move and as sign of protest left the Parliament arliament sending a protest note to Ahmet Zog for the mistake he had made by abolishing them. On December 25, 1921, the Prime Minister, Xhaferr Ypi, appointed Ahmet Zog Minister of Interior Affairs. Under the necessity of modernizing the Albanian state the new political post allowed Zog, to establish order and peace in the country and take a series of measures to concentrate power in his hands. ${ }^{76}$

In February 1922, the authority and politics pursued by Ahmet Zog intensified, and the popular resentment of people with advanced democratic ideas and those who opposed Zog as a political leader fueled hostility not only within the government but also outside it. Such hostility gave rise to an antiZogist movement led by Fan Noli, Luigj Gurakuqi, Hasan Prishtina, Hoxha Kadri, Bajram Curri and others.

In the new elections of December 27, 1923 Hoxha Kadri was elected MP and representative of Kosovo, along with Avni Rustemi, Dervish Mitrovica, Niman Ferizi, and Dr. Fahri Reshid. This group of MPs was known by the common people as the "Hoxha Kadri group". During this period, the Kosovo Committee and especially Hoxha Kadri worked closely with Avni Rustemi, a prominent patriot and leader of the "Bashkimi" society. At that

${ }^{73}$ AQSh, Fondi. 422, Viti 1921, Dos. 4, Decree appointing once Minister of Justice and later President of the Dictatorship Court, 1921.

${ }^{74}$ National Council, ibid., p.17.

${ }^{75}$ Noel Malkolm, Kosovo, a short history, transl. Abdullah Karjagdiu, Koha, Prishtinë 1998, p. 288.

${ }^{76}$ Duka, ibid., p. 137. 


\section{ILIRJANA KACELI}

time, this society attempted to assassinate Ahmet Zog inside the Pparliament. The attempt led to new political developments in Albania. Zog was forced to temporarily leave the political life. He had proclaimed Avni Rustemi directly responsible for the assassination attempt being leader of the "Bashkimi" society. Considering the course of events, and given that Zog's possible return to politics would potentially pose a danger to his friend, Hoxha Kadri Prishtina tried to help Avni Rustemi leave abroad by providing him with a fake passport.

On May 5, 1924, while walking in the streets of Tirana along with Hoxha Kadri, Avni Rustemi was shot dead by an assassin. Although not in good health, Hoxha Kadri tried to shoot at the killer. This shocking event for the progressive public in Albania brought the June Movement led by Fan Noli, who came to power in June 1924. Even during Noli's rule, the Kosovo Committee drafted a series of protests sent to the League of Nations against both the colonization and occupation of Kosovo by Yugoslav occupiers. In September 1924, the Committee sent a delegation to Geneva to protest at the League of Nations against Serbian barbarism in Kosovo and the open preparations of Serbian and Zogist forces to intervene in Albania.

The members of the delegation were Hasan Prishtina, Bajram Curri and Bedri Pejani who wrote in the draft protest; "This regime of iron, fire and extortion is the main cause of mass emigration of the Albanian population to Turkey, which is done in terrible conditions that cost the lives of hundreds of families, and the rest are sentenced to incurable misery". ${ }^{77}$ Fan Noli's government stayed in power for only six months. Zog's disagreements with the Kosovo Committee in Albania continued even after Zog's return from Belgrade. Apparently he had promised Belgrade that he would stop the Kosovo Committee.

In fact, after his return, a large part of the Kosovo elite that had previously settled in Albania due to the opposition to his policy, was faced with two alternatives: either to surrender or to leave the country. In this period, the political activity of the Committee is interrupted due to the alignment of its main personalities with the Government of Fan Noli.

\footnotetext{
77 Jup Kastrati, Hoxha Kadriu- $40^{\text {th }}$ anniversary announcement), Buletini ILPSH, Number 3 , Shkodër 1965, p. 439.
} 


\section{THE RELATIONS BETWEEN KOSOVO NATIONAL PROTECTION COMMITTEE AND THE ALBANIAN GOVERNMENT DURING (1918-1924)}

On December 25, 1924, Ahmet Zog entered Tirana with his army and overthrew Noli's government. Fan Noli and his supporters were forced to leave Albania. Under these conditions, Hoxha Kadri himself, as Zog's opponent, left the country together with Bedri Pejani, Bajram Curri and others causing the interruption of the activity of the Kosovo Committee in Albania. The National Defense Committee of Kosovo was headed by Hoxha Kadri from its establishment in May 1918 until December 1924, year in which Hasan Prishtina assumes control (1925-1933).

However, even later than 1924, Hasan Prishtina had not stopped the efforts for the liquidation of Ahmet Zog and the destabilization of his regime. ${ }^{78}$ Ahmet Zog, aiming at the stabilization of the state - a necessity for the current circumstances-, had some incompatibility with the Kosovo nationalists, who approached the problem of Kosovo sensationally and not focusing on the real possibilities that the Albanian state had at that period. ${ }^{79}$

Zog, in the wave of a pragmatist policy, was interested, firstly, on peace and order in the country and secondly, in a balanced policy with the Balkan countries. Ahmet Zog sought the support of the Great Powers to maintain a status quo in the Balkans although nationalist movements were not supported in the region. In this climate, it was impossible for the opposition activity of the Kosovo Committee to take place in Albania, but during this period its members would act only abroad as opponents of Zog's regime.

\section{Conclusion}

The Kosovo National Protection Committee and its national patriotic activity left a considerable mark in the history of the Albanian people. The Committee and its leaders managed to occupy an important and beloved place in people's minds. This is best displayed throughout its activity. The role of the Kosovo Committee has been prominent and relevant in the ongoing fight for the unification of the shattered Albanian territories, as well as against the annexation by neighboring chauvinist claimants of the Albanian territories, especially of the main cities such as Shkodra, Vlora, Gjirokastra and Korça. The KNP Committee and its chairman have always fought for nationwide

\footnotetext{
${ }^{78}$ Marenglen Verli, "The Concern of the Albanians in Jugoslavia during the 20s-30s of the 20 th century", Kosova, Number 31-32, Prishtinë 2009, p. 39.

79 Culaj, "King Zog's governments for the National Issue", Gjurmime Albanologjike, Seria e Shkencave Historike, Number 49, Prishtinë 2019, p. 270.
} 
unity, not only in the people, in the Council of the Committee but also in the National Council. All the political and diplomatic activity of the KNP Committee was directed and has always served the interests of the Albanian people and nation. The KNP Committee has always been present at the right moment, providing assistance in saving Albania from the claims and revenge of its neighbouring countries. At the same time, the Committee unconditionally supported the Albanian people left outside the political borders of Albania, aiming at their liberation and unification with their native land.

\section{BIBLIOGRAPHY}

\section{Archival Documents}

AQSH-Arkivi Qendror Shqiptar (The Central State Archive of Albania)

Fondi 446- Komiteti Mbrojtja Kombëtare e Kosovës 1918-1924

Fondi 422 - Hoxhë Kadriu-Kadri Prishtina

Fondi 152- Kongresi i Lushnjës

AMG- Archives du Ministére de la Guerre de France. Archives historiques de l'Armee de Terre (Guerre 1914-1918).

AMAE - Archives du Ministére des Affaires Etrangéres de France. Arcives Diplomatiques Serie: Europe 1918-1929, Albanie, vol.10.

\section{Newspaper}

Populli, Shkodër

Bujku, Prishtinë

\section{Books And Articles}

AHMETAJ, Lavdosh, Albania Paris Peace Conference and Albanian Delegations 1918-1921, Vestprint, Tiranë 2012.

AQIF PASHË ELBASANI (1860-1926), Summary of documents, Edit. M. Belegu, H. Kordha\& R. Mita, Bashkia Elbasan, Tiranë 2012. 


\section{THE RELATIONS BETWEEN KOSOVO NATIONAL PROTECTION COMMITTEE AND THE ALBANIAN GOVERNMENT DURING (1918-1924)}

BAJRAMI, Hakif, Bedri Pejani: a life and a death for ethnic Albania 18851946, Fjala, Prishtinë 1994.

BISEDIMET E KËSHILLIT KOMBËTAR, 1920/ 1921, Shtypshkronja Mbrothësia, Tiranë 1923.

ÇAMI, Muin, "On the establishment of the Committee "National Defense of Kosovo", and its political orientation", in: (Përmbledhjen me kumtesa) Komiteti Mbrojtja Kombëtare e Kosovës, Akademia e Shkencave të Shqipërisë, Instituti i Historisë-Tiranë, Instituti i Historisë-Prishtinë, Tiranë 2004, pp. 42-51.

, \& VERLI, M, Albania at the Peace Conference (1919-1920).

Akademia e Shkencave të Shqipërisë, Kristalina-KH, Tiranë 2015.

CASTELlAN, Georges, Histori e Ballkanit, (Transl: Arben Puto\& Luan Omari) Çabej, Tiranë 1996.

CULAJ, Lush, "King Zog's governments for the National Issue", Gjurmime Albanologjike, Seria e Shkencave Historike, no.49, Prishtinë 2019, pp. 267281.

Kosovo National Protection Committee 1918-1924, Instituti Albanologjik i Prishtinës, Prishtinë 1997.

DOBRUNA, Alban, "Gjakova and Kosovo National Protection Committee (1918-1924)", Historical Science Series, Gjurmime Albanologjike, No.48/Prishtinë 2018, pp. 181-193.

"The Contribution of Islamic Tariqats to the Kosovo

National Protection Committee”, Univers, Tiranë 2020, pp. 67-75.

DOÇI, Pal, Hoxha Kadri Prishtina life and works, Geer, Tiranë 2005.

DUKA, Valentina, History of Albania 1912- 2000, ShBLU, Tiranë 2007.

ELSHANI, Milazim, The Albanian state and Kosovo 1912-1939, University of Tirana, Faculty History-Philology, Unpublished Doctoral Thesis, Supervisor: Prof. Dr. Vlentina Duka, Tiranë 2016. 


\section{ILIRJANA KACELI}

GENERAL G.F. PHILLIPS AND KOSOVO NATIONAL PROTECTION COMITTE, Historical documents from Britanic Archive 1913-1921, (Eds.) E. Çeku dhe B. Destani, Tiranë \& Londër, Instituti i Çështjeve Kombëtare, Qendra për Studime Shqiptare, Tiranë 2015.

HASAN PRISHTINA, Summary of Documents 1908-1934, Edit. Kujtim Nuro \& Nezir Bata, 8 Nëntori, Tiranë 1983.

HISTORIA E POPULLIT SHQIPTAR, Volume III, Toena, Tiranë 2007.

KASTRATI, Jup, "Hoxha Kadri- 40 th anniversary announcement", Buletin ILPSH, no. 3, Shkodër 1965, pp. 433-441.

MALKOLM, Noel. Kosovo, a Short History, (Transl; Abdullah Karjagdiu), Koha, Prishtinë 1998.

MILO, Paskal, Politika e Jashtme e Shqipërisë, (1912-1939), Volume I, Toena, Tiranë 2013.

MITA (TODRI), Rudina \& Kordha, Hysen, Albanian political pluralism during the period 1914-1924, Ramagraf, Elbasan 2012.

NOSI, Lef. Dokumente Historike 1912-1918, Instituti i Historisë, Tiranë 2007.

PRIFTI, Kristaq \& Shtylla, Zamir, "Komiteti Mbrojtja Kombëtare e Kosovës dhe veprimtaria e tij për çlirimin dhe unitetin kombëtar", Studime Historike, nr. 4, Tiranë 1988, pp.137-149.

"Contribution of the "MCR" Committee for the restoration of Albania's independence and for national unification (1918-1924)," in: (Summary with paper releases Kosovo National Protection Committee, Akademia e Shkencave të Shqipërisë; Instituti i Historisë-Tiranë, Instituti i Historisë- Prishtinë, Tiranë 2004, pp. 16-32.

RIFATI, Fitim, Kosova gjatë Luftës së Parë Botërore, Insituti i Historisë Kosovë, Prishtinë 2019. 
THE RELATIONS BETWEEN KOSOVO NATIONAL PROTECTION COMMITTEE AND THE ALBANIAN GOVERNMENT DURING (1918-1924)

, Organizatat Pararendëse të Komitetit "Mbrojtja Kombëtare e Kosovës” (1913-1916), Instituti i Historisë Prishtinë, Kosova, no. 44, Prishtinë 2019, pp. 277-285.

SHALA, Xheladin, "The role of the "KNP" Committee in the AlbanianSerbian wars during the years 1918-1921", in: Summary with paper releases Kosovo National Protection Committee, Akademia e Shkencave të Shqipërisë, Tiranë 2004, pp. 109-129.

SHTYLLA, Zamir, "About the Establishment of the Activity of the Committee Kosovo National Protection in the years 1918-1920", Studime Historike, Akademia e Shkencave e RPSH: Instituti i Historisë, Year XXXX (XXIII), No. 3, Tiranë 1986, pp. 97-115.

SKENDI, Eqber, Hoxhë Kadriu (Kadri Prishtina), Rilindja, Prishtinë 1992.

THE STRUGGLE OF THE ALBANIAN PEOPLE FOR NATIONAL LIBERATION 1918-1920, (Summary with documents), Volume I, Edit. Muin Cami \& Hidajete Luga (Bejtja), Akademia e Shkencave, Institute of History \& General Directorate of Archives, Tiranë 1975.

VLLAMASI, Sejfi, Ballafaqime Politike në Shqipëri (1897-1942), Marin Barleti, Tiranë 1995.

VLORA, Eqerem Bej, Memories 1885-1925, (transl.) Afrim Koçi, Shtepia e Librit dhe Komunikimit, Tiranë 2003.

XHAFA, Bajram, Lufta e Dibres 1920: qëndresa dibrane ndaj pushtimit ushtarakjugosllav në vitet 1918-1921, Camaj-Pipa, Shkoder 2001. 